\title{
Australian Journal of

\section{Glyphosate resistant soybean growth and yield affected by glyphosate and phosphate fertilization}

\author{
Arthur Arrobas Martins Barroso*, Leonardo Bianco de Carvalho \\ Universidade Estadual Paulista, UNESP. Via de Acesso Prof. Paulo Donato Castellane, s/n Rural. 14884900, \\ Jaboticabal, SP, Brazil
}

*Corresponding author: arthuragro07@hotmail.com

\begin{abstract}
Glyphosate is the most used herbicide worldwide and glyphosate-tolerant soybean planted in almost all cultivated areas. In Brazil, the area cultivated with transgenic soybean reaches more than $90 \%$. Recently, the application of glyphosate in tolerant soybean has assumed the possibility to injury the crop under certain conditions and herbicides formulations. Phosphate fertilization can directly influence glyphosate uptake in plants because glyphosate translocation inside cells is related with phosphate transporters. Therefore, a study was conducted in two steps intended to determine if different doses of phosphate fertilization and/or glyphosate mode of spraying could modify glyphosate susceptibility of glyphosate-tolerant soybean, affecting crop development and yield. We tested two glyphosate doses and its interaction with mode of spraying and different glyphosate doses interaction with phosphate soil-fertilization. Experiment I was set up in a two by two factorial design, testing two doses of isopropylamine salt glyphosate ( 960 and $1,440 \mathrm{~g}_{\text {ae }} \mathrm{h}^{-1}$ ) and two modes of glyphosate application (single spraying and sequential spraying). Experiment II was set up in a two by three factorial design, testing two doses of glyphosate (960 and 1,440 $\mathrm{g}_{\text {ae }} \mathrm{ha}^{-1}$ ) and three doses of phosphate fertilization $\left(54,108\right.$ and $162 \mathrm{~kg} \mathrm{ha}^{-1}$ of $\left.\mathrm{P}_{2} \mathrm{O}_{5}\right)$. In both experiments, weed community was evaluated based on number of individuals and their respective dry mass accumulation. Crop was evaluated in dry mass of leaves, dry mass of stem, dry mass of pods, dry mass of shoot, plant height and grain yield. The use of glyphosate in a sequential spraying $\left(960+480 \mathrm{~g}\right.$ ae ha $\left.{ }^{-1}\right)$ or in higher dose $\left(1,440 \mathrm{~g}_{\text {ae }} \mathrm{ha}^{-1}\right)$ provides a highly efficient weed control and a high-performance crop growth and yield. The additional soil-fertilization with phosphate in this case does not affect soybean since no crop injury was observed.
\end{abstract}

Keywords: Glycine max, glyphosate tolerance, phosphate fertilizers, phytotoxicity; transgenic.

Abbreviations: DAE_Days after crop emergence.

Introduction

Glyphosate ( $N$-(phosphonomethyl) glycine) is the most used herbicide worldwide. Glyphosate is a nonselective wide spectrum post-emergence herbicide translocated throughout the plant to actively growing tissues. In cells, it inhibits 5-enolpyruvylshikimate-3-phosphate synthase. The first visible symptom of glyphosate toxicity in susceptible plants generally is the appearance of chlorosis in new formed leaves. Subsequent symptoms include bleaching, chlorosis and stunted soybean growth (Fuchs et al., 2002). The inhibition of EPSPS results in a decline of protein, vitamin cofactors, secondary metabolites, and photosynthesis, resulting in plant death (Duke and Powles, 2008). Transgenic glyphosate-resistant (GR) soybean [Glycine $\max$ (L.) Merr.] is a result of the insertion of a bacterial gene that encodes a glyphosate-insensitive EPSPS enzyme. Expression of this EPSPS prevents the metabolic disruption caused by inhibition of the shikimate pathway (Funke et al., 2006). This biotechnology has provided new opportunities for growers, by enabling effective weed control with a single herbicide use (Gianessi, 2008). The ease of use of this technology caused an expansion of GR cultivated area worldwide. In Brazil, GR soybean is planted in 32.7 millions of hectares (Celeres, 2017).

Although GR soybean is resistant to glyphosate, last years, application of glyphosate resulted in significant crop injury under certain conditions and herbicides formulations (Albrecht et al., 2014a). Recent studies have shown that glyphosate can have phytotoxic effects on soybean by affecting process as secondary metabolism, mineral nutrition, photosynthesis and biomass accumulation (Reddy et al., 2004; Zobiole et al., 2010a; Zobiole et al., 2010b; Zobiole et al., 2011; Zobiole et al., 2012). In addition, different modes of glyphosate application, as time and sequential applications can play an important role in these deleterious effects (Albrecht et al., 2014b). Phosphate is an essential nutrient for plants, participating in crucial metabolic events, such as energy transfer and protein metabolism. Phosphate fertilization of soil is a common agricultural practice to assure plant growth and development and a common practice in soybean cultivation (Brahim et al., 2017; Zanatta et al., 2017). Phosphate fertilization can influence glyphosate uptake in plants because glyphosate translocation inside cells is generally 
related with phosphate transporters (Zanatta et al., 2017). These transporters play an important role in phosphate absorption in plants because, generally, phosphate is presented in insoluble forms in soils being quenching with cations and organic compounds (Hirsch et al., 2006). Because of this, plants developed strategies for this mineral uptake so they can induce the expression of high-affinity phosphorus carries, enhancing phosphorus uptake, what can enhance glyphosate translocation too (Bayle et al., 2011).

Another impact is that high rates of phosphate can remobilize small amounts of glyphosate bound to soil, being these toxic to the soybean (Duke et al., 2012). Some authors related these interactions between glyphosate and phosphate but at the most case, little is done evaluating crops yield (Hetherington et al., 1998). The research objective of this paper was to determine if different doses of phosphate fertilization and/or glyphosate mode of application could modify glyphosate sensitivity in glyphosate-resistant soybean, affecting crop development and yield. The raise of this information should benefit growers to manage herbicide application within phosphate soil fertilization.

\section{Results and Discussion}

\section{Glyphosate doses and modes of spraying}

No interaction ( $P>0.05$ ) between doses of glyphosate and modes of spraying glyphosate was observed for all characteristics of both weed community and crop. However, the main effect of the dose of glyphosate and the mode of spraying glyphosate was independently significant for almost all characteristics evaluated in both weed community $(P<0.01)$ and crop $(P<0.05)$, excepting for the number of individuals of weed community $(P>0.05)$ and the plant height of crop $(P>0.05)$.

Sequential spraying of glyphosate reduced by $\sim 67 \%$ the number of individuals of the weed community $\left(\sim 4\right.$ plants $\mathrm{m}^{-}$ ${ }^{2}$ ) in comparison to a single spraying ( 12 plants $\left.\mathrm{m}^{-2}\right)$, independently on the dose of glyphosate (Fig 1). The highest dose of glyphosate and the sequential spraying reduced the dry mass accumulation of the weed community by $\sim 52 \%$ $\left(21.8\right.$ grams $^{-2}$ ) and $\sim 4 \%$ (13.8 grams $\left.\mathrm{m}^{-2}\right)$, respectively, in comparison to the lowest dose $\left(45.2\right.$ grams $\left.^{-2}\right)$ and the

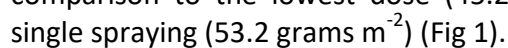

As glyphosate is a wide-spectrum herbicide, and as no tolerant species were found in our experiments, we can assume satisfactory levels of weed control obtained, specially by using sequential spraying and high dose of glyphosate, as observed by other authors (Ferrell and Witt, 2002). According to Culpepper et al. (2000), sequential spraying of glyphosate generally provides higher levels of weed control due probably to controlling several flux of weed emergence; and higher productivity of soybean is obtained by using higher doses of glyphosate, what explains the low number of individuals at the soybean harvest.

The sequential spraying of glyphosate improved the control of weeds, as well as the highest herbicide dose did, with respect to the reduction of both number of individuals and plant biomass. Therefore, soybean crop reached the best development characteristics, in those experimental situations, providing higher crop productivity.
The highest dose of glyphosate increased the dry mass of leaves ( 7.8 grams plant $\left.^{-1}\right)$, dry mass of stems (10.0 grams plant $\left.^{-1}\right)$, dry mass of pods (10.6 grams plant $\left.{ }^{-1}\right)$, dry mass of shoot (28.6 grams plant $\left.{ }^{-1}\right)$ and the crop yield $\left(3,297 \mathrm{~kg} \mathrm{ha}^{-1}\right)$ by $\sim 18 \%, \sim 14 \%, \sim 20 \%, \sim 19 \%$ e $\sim 13 \%$, respectively, not influencing on the plant height (Fig 2).

In addition, the sequential spraying of glyphosate increased the dry mass of leaves ( 8.2 grams plant $^{-1}$ ), dry mass of stems (10.6 grams plant $\left.{ }^{-1}\right)$, dry mass of pods (10.8 grams plant $\left.{ }^{-1}\right)$, dry mass of shoot (29.6 grams plant ${ }^{-1}$ ) and the crop yield $\left(3,578 \mathrm{~kg} \mathrm{ha}^{-1}\right)$ by $\sim 32 \%, \sim 29 \%, \sim 27 \%, \sim 28 \%$ e $\sim 13 \%$, respectively, not influencing on the plant height (Fig 3).

\section{Glyphosate and phosphate fertilization}

No interaction $(P>0.05)$ between doses of glyphosate and doses of phosphate fertilization was observed for all characteristics of both weed community and crop. However, the main effect of the dose of glyphosate and the dose of phosphate fertilization was independently significant for almost all characteristics evaluated in both weed community $(P \leq 0.01)$ and crop $(P \leq 0.05)$, excepting for the number of individuals of weed community $(P>0.05)$ and the plant height of crop ( $P>0.05)$.

The use of phosphate fertilization with doses of $\mathrm{P}_{2} \mathrm{O}_{5}$ up to $122 \mathrm{~g} \mathrm{ha}^{-1}$ increased the number of individuals of the weed community (maximum number of individuals $\sim 5$ plants $\mathrm{m}^{-2}$ ) independently on the dose of glyphosate (Fig 4). On the other hand, the highest dose of glyphosate reduced the dry mass accumulation of the weed community by $\sim 84 \%$ (3.8 grams $\mathrm{m}^{-2}$ ) in comparison to the lowest dose (23.9 grams $\mathrm{m}^{-}$ $\left.{ }^{2}\right)$ (Fig 4). In addition, the fertilization by using up to $161 \mathrm{~g}$ ha

${ }^{1}$ of $\mathrm{P}_{2} \mathrm{O}_{5}$ increased the dry mass accumulation of the weed community (maximum dry mass accumulation $\sim 21.7$ grams $\mathrm{m}^{-2}$ ) (Fig 4).

When phosphate was applied into the soil, the number of weeds and the respective weed community biomass accumulation increased. The phosphate fertilization also provided a better development of soybean crop. Therefore, the glyphosate provided an efficient control of weeds, even that the crop was infested by a more developed weed community. However, the application of glyphosate in more developed weeds can provide lower levels of control, depending on the weed species presented in the field (Culpepper et al., 2000). In addition, the application of phosphate, in this case, probably did not alter the absorption/translocation of glyphosate in soybean to cause impact on crop productivity. The highest dose of glyphosate increased the dry mass of leaves ( 8.8 grams plant $^{-1}$ ), dry mass of stems (11.3 grams plant $\left.{ }^{-1}\right)$, dry mass of pods (11.6 grams plant $\left.{ }^{-1}\right)$, dry mass of shoot (32.0 grams plant $\left.{ }^{-1}\right)$ and the crop yield $\left(3,577 \mathrm{~kg} \mathrm{ha}^{-1}\right)$ by $17 \%, \sim 13 \%, \sim 17 \%, \sim 18 \% \mathrm{e}$ $\sim 13 \%$, respectively, not influencing on the plant height (Fig 5).

In addition, the use of phosphate fertilization with doses of $\mathrm{P}_{2} \mathrm{O}_{5}$ up to $131 \mathrm{~kg} \mathrm{ha}^{-1}$ increased the dry mass of leaves, dry mass of pods, dry mass of shoot and the crop yield at maximum average values of 8.7 grams plant $^{-1}, 11.4$ grams plant $^{-1}, 31.3$ grams plant $^{-1}$ and $3,577 \mathrm{~kg} \mathrm{ha}^{-1}$, respectively; and the increase of the dry mass of stem occurred by using $132 \mathrm{~kg} \mathrm{ha}^{-1}$ of $\mathrm{P}_{2} \mathrm{O}_{5}$, at a maximum mean value of 11.2 grams plant $^{-1}$ (Fig 6). The fertilization with 54 up to $162 \mathrm{~kg} \mathrm{ha}^{-1}$ of 

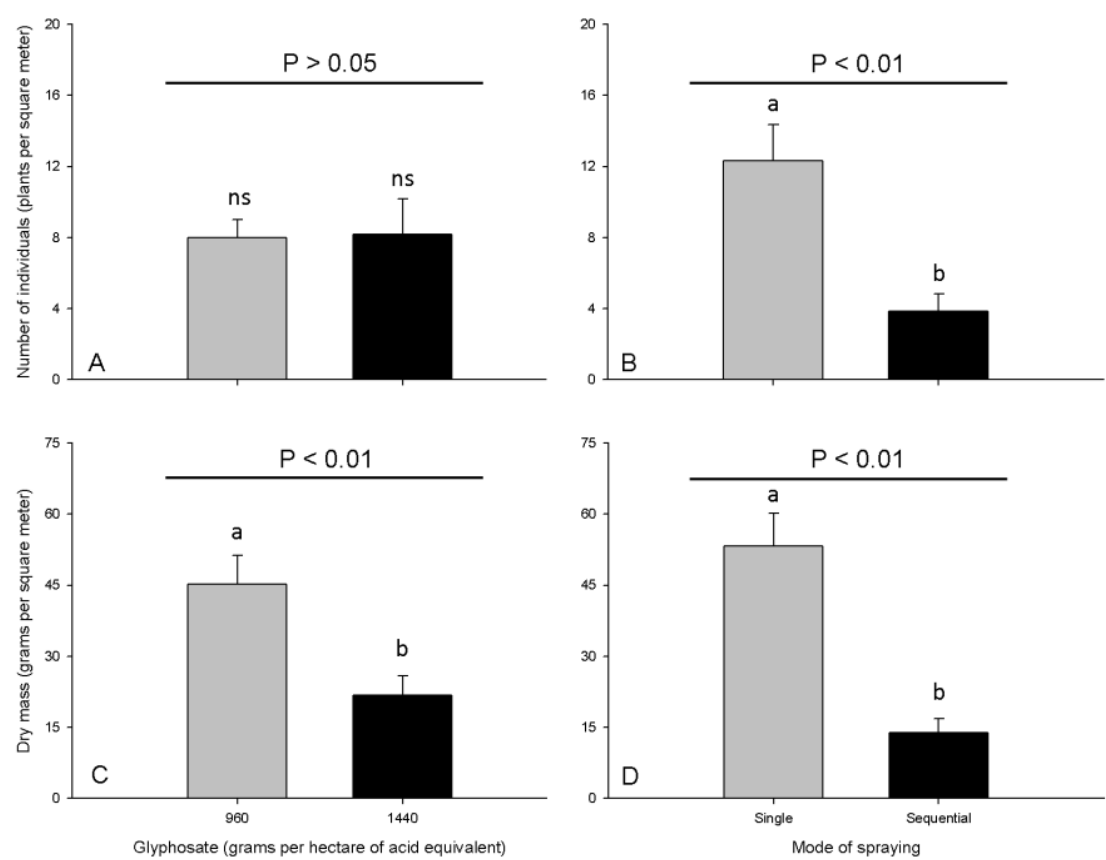

Fig 1. Number of individuals ( $A$ and $B$ ) and shoot dry mass ( $C$ and $D)$ of a weed community infesting soybean crop in two doses of glyphosate (960 and 1,440 $\mathrm{g}_{\text {ea }} \mathrm{ha}^{-1}$ ) applied under two modes of spraying ( $\mathrm{A}$ and $\mathrm{C}$ - main effect of doses), (B and D - main effect of modes). Vertical lines indicate the standard error of mean and $P$ indicates the significance by the $F$ test.
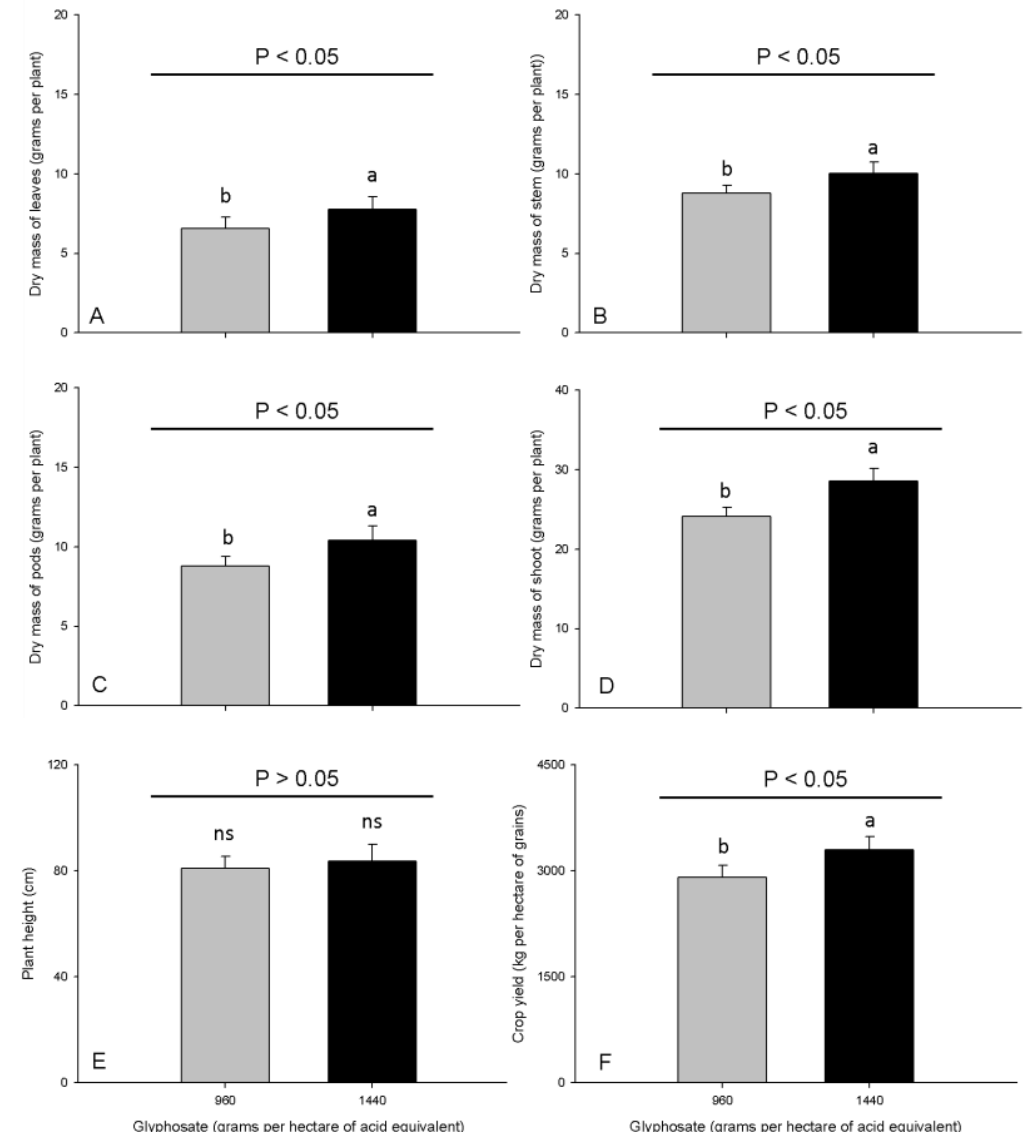

Fig 2. Dry mass of leaves (A), stem (B), pods (C), shoot (D), plant height (E), and crop yield (F) of a soybean field where two doses of glyphosate were applied ( 960 and 1,440 $\mathrm{g}_{\text {ea }} \mathrm{ha}^{-1}$ ) under two modes of spraying to control a weed community. Graphs show the main effect of the doses of glyphosate. Vertical lines indicate the standard error of mean and $P$ indicates the significance by the $F$ test. 

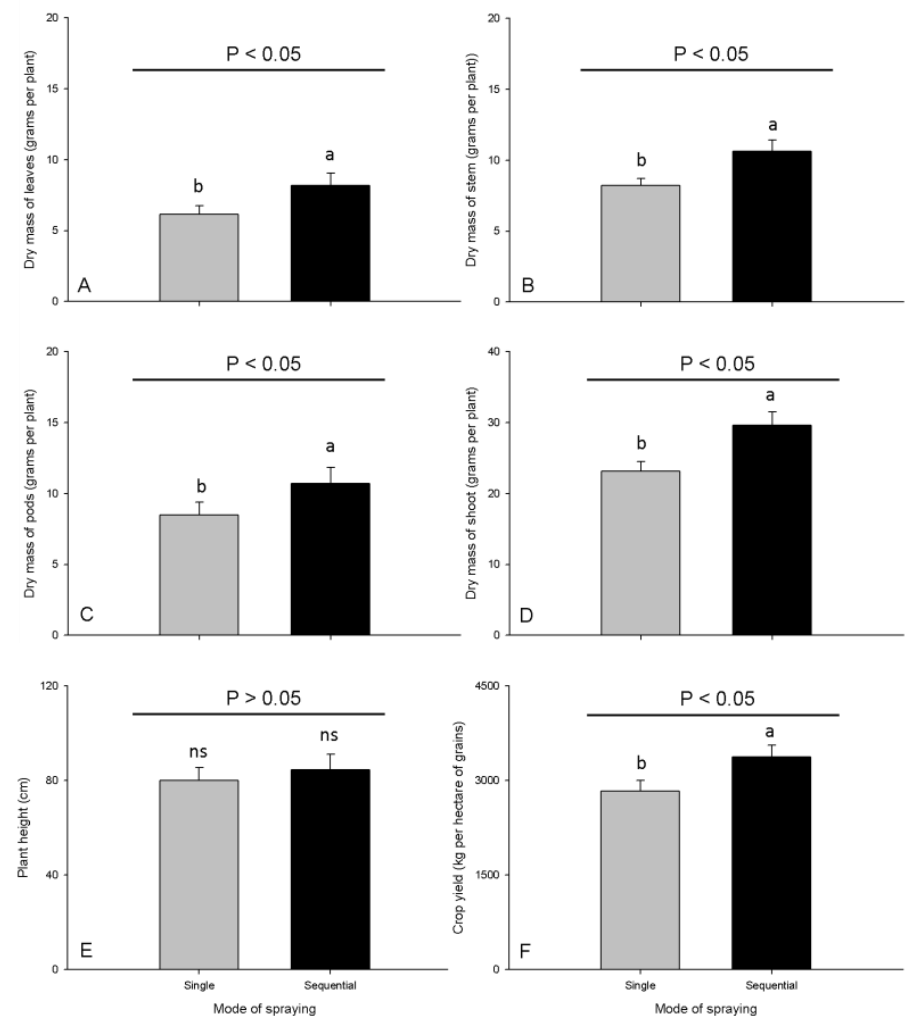

Fig 3. Dry mass of leaves (A), stem (B), pods (C), shoot (D), plant height (E), and crop yield (F) of a soybean field where two doses of glyphosate were applied $\left(960\right.$ and $1,440 \mathrm{~g}$ ea ha ${ }^{-1}$ ) under two modes of spraying to control a weed community. Graphs show the main effect of the modes of spraying. Vertical lines indicate the standard error of mean and $P$ indicates the significance by the $F$ test.
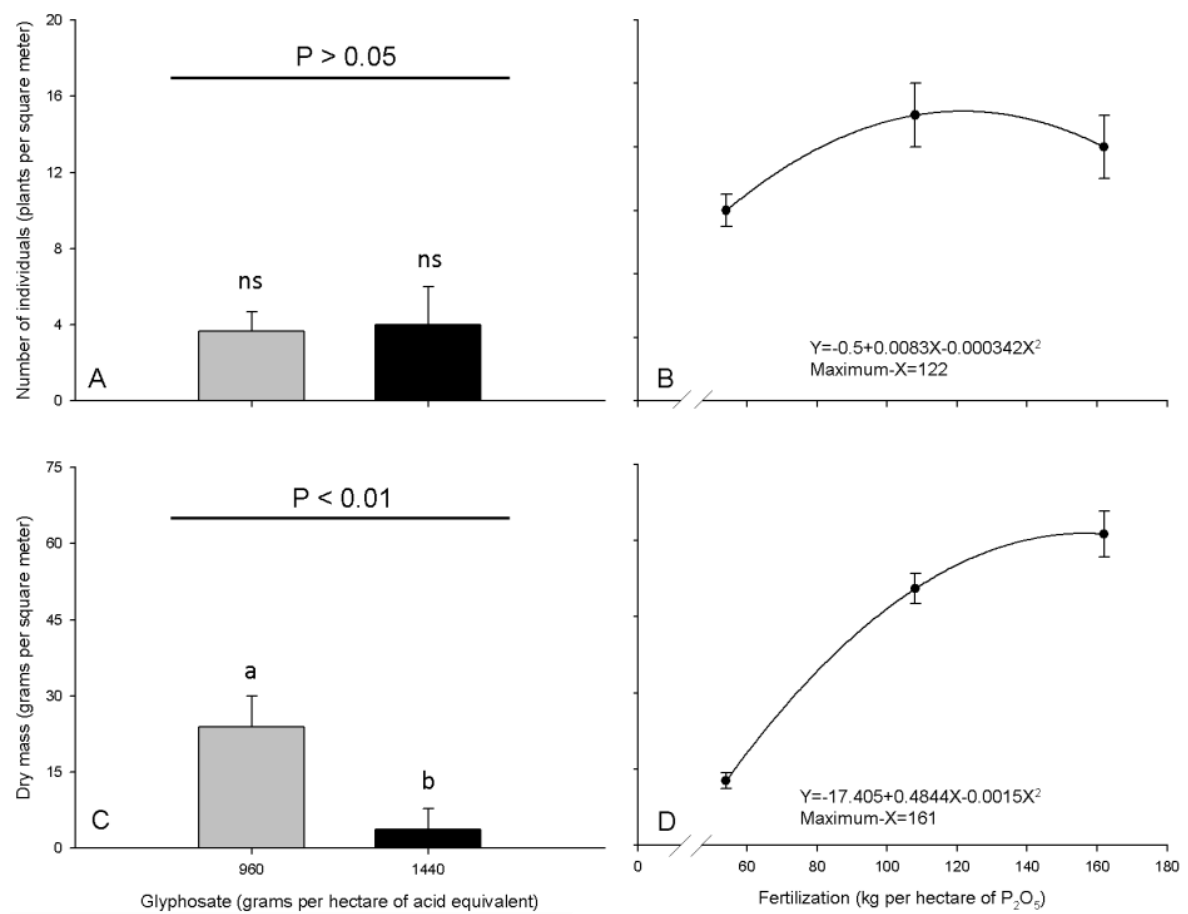

Fig 4. Number of individuals $(A$ and $B$ ) and shoot dry mass ( $C$ and $D)$ of a weed community infesting soybean crop in that two doses of glyphosate ( $A$ and $C$ - main effect of the herbicide) were sprayed to control weeds after three doses of phosphate were applied into the soil ( $B$ and $D$ - main effect of the fertilizer). Vertical lines indicate the standard error of mean and $P$ indicates the significance by the $\mathrm{F}$ test. 

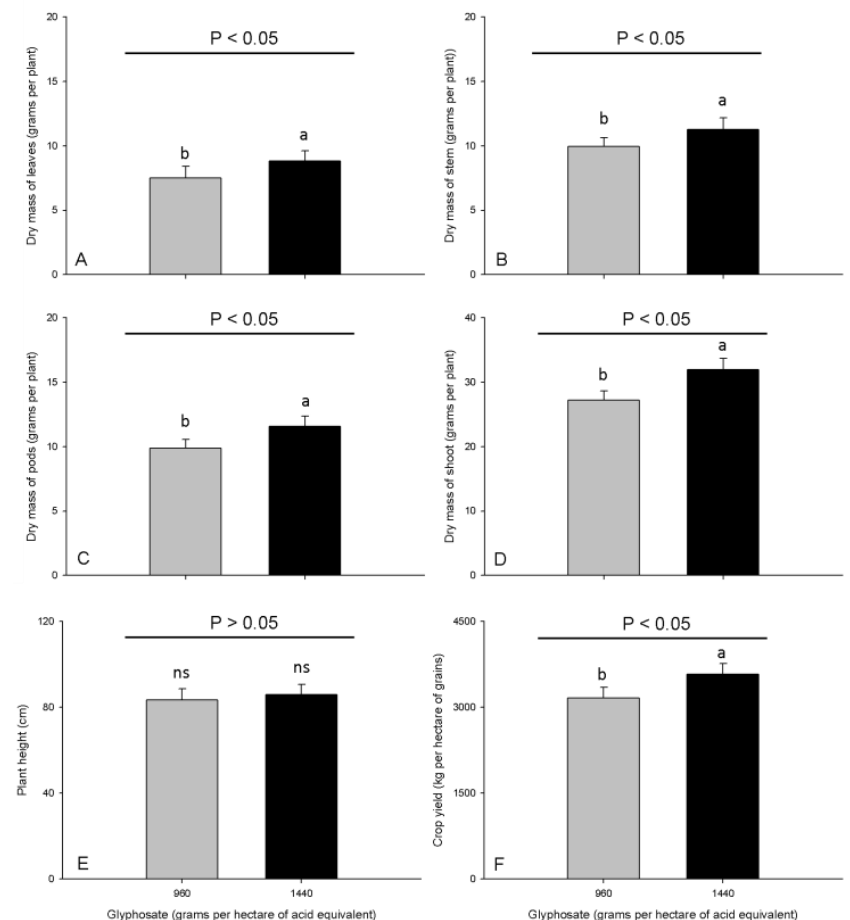

Fig 5. Dry mass of leaves (A), stem (B), pods (C), and shoot (D), plant height (E), and crop yield (F) of a soybean field where two doses of glyphosate ( 960 and 1,440 $\mathrm{g}_{\text {ea }} \mathrm{ha}^{-1}$ ) were sprayed to control weeds after three doses of phosphate applied into the soil. Graphs show the main effect of the herbicide dose. Vertical lines indicate the standard error of mean and $P$ indicates the significance by the $\mathrm{F}$ test.
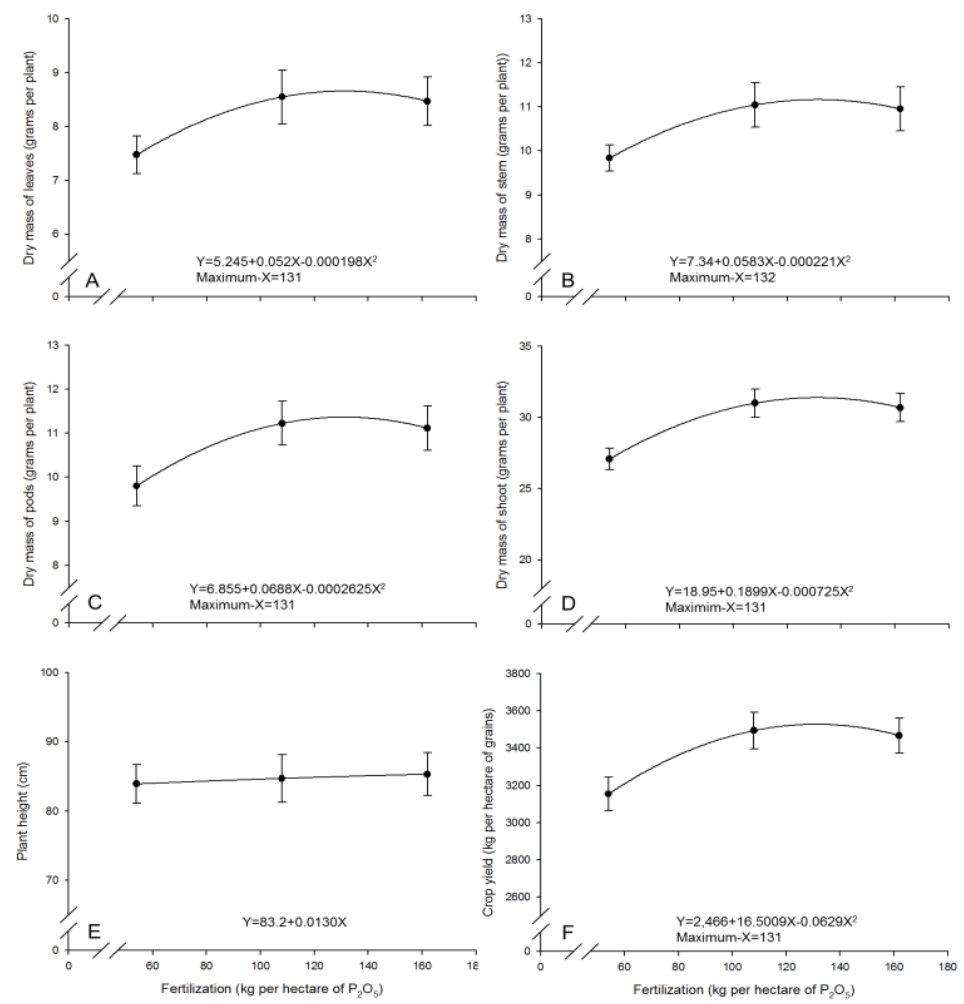

Fig 6. Dry mass of leaves (A), stem (B), pods (C), and shoot (D), plant height (E), and crop yield (F) of a soybean field in that two doses of glyphosate were sprayed to control weeds after three doses of phosphate were applied into the soil. Graphs show the main effect of the fertilizer. Vertical lines indicate the standard error of mean. 
$\mathrm{P}_{2} \mathrm{O}_{5}$ increased linearly the crop plant height (Fig 6) at a rate of $1.3 \mathrm{~mm}$ per $10 \mathrm{~kg} \mathrm{ha}^{-1}$ of $\mathrm{P}_{2} \mathrm{O}_{5}$.

In our two experiments, glyphosate does not affect soybean. However, there are reports indicating that a sequential spraying of glyphosate caused toxic effects on soybean, increasing the time required to ensure the closing canopy of crop (Alonso et al., 2013; Albrecht et al., 2014b; Gomes et al., 2017; Krenchiski et al., 2017). According to these authors, the toxic effects occur due to a sum of stresses caused by the herbicide in a sequential spraying as well as the effects on plant physiology.

The use of glyphosate in a sequential spraying $(960+480 \mathrm{~g}$ $\mathrm{ha}^{-1}$ of acid equivalent) or in a single dose $\left(1,440 \mathrm{~g} \mathrm{ha}^{-1}\right.$ of acid equivalent) provided a highly efficient weed control and guarantees, consequently, a high-performance of crop growth and yield. The additional soil-fertilization with phosphate $\left(\sim 131 \mathrm{~kg} \mathrm{ha}^{-1}\right.$ of $\left.\mathrm{P}_{2} \mathrm{O}_{5}\right)$ increased the weed community growth, independently on the herbicide dose, but is also a guarantee a better crop performance where glyphosate was applied in higher doses. The phosphate fertilization in this case does not interfered in soybean response to glyphosate.

\section{Materials and Methods}

\section{Plant material and growing conditions}

Two experiments were carried out using a glyphosatetolerant soybean (CD2585RR, Monsanto ${ }^{\circledR}$, São José dos Campos, Brazil). Field trials were located at an experimental area in the South of Brazil $\left(21.25^{\circ} \mathrm{S}, 48.31^{\circ} \mathrm{W}\right.$ and $825-\mathrm{m}$ altitude), with a mean temperature of $\sim 16{ }^{\circ} \mathrm{C}$, a mean relative air humidity of $\sim 74 \%$ and an accumulated rainfall of $195 \mathrm{~mm}$ during the experimental stage. Argillaceous Aluminous Humic Cambisol soil characteristics $(0-20 \mathrm{~cm})$ were: $\mathrm{pH}$ (water) $=5.1 ; \mathrm{OM}=3.8 \% ; \mathrm{P}($ resin $)=2.9 \mathrm{mg} \mathrm{dm}^{-3} ; \mathrm{K}$ $=80.0 \mathrm{mg} \mathrm{dm}{ }^{-3} ; \mathrm{Ca}=4.6 \mathrm{cmol}_{\mathrm{c}} \mathrm{dm}^{-3} ; \mathrm{Mg}=3.5 \mathrm{cmol}_{\mathrm{c}} \mathrm{dm}^{-3} ; \mathrm{Na}$ $=10.0 \mathrm{mg} \mathrm{dm}^{-3} ; \mathrm{Al}=1.3 \mathrm{cmol}_{\mathrm{c}} \mathrm{dm}^{-3} ; \mathrm{H}+\mathrm{Al}=13.7 \mathrm{cmol}_{\mathrm{c}} \mathrm{dm}^{-3}$; $\mathrm{CEC}=9.6 \mathrm{cmol}_{\mathrm{c}} \mathrm{dm}^{-3} ; \mathrm{SB}=8.4 \mathrm{cmol}_{\mathrm{c}} \mathrm{dm}^{-3}$; and $\mathrm{V}=37.8 \%$. Soil acidity were correct similarly in both experiments by liming as recommended by the Brazilian Society of Soil Science (SBCS, 2004).

Soybean was mechanically sowed in $50-\mathrm{cm}$ rows width, with an estimated population of 300,000 plants per hectare, in both experiments. The experimental units corresponded to four lines, $5-\mathrm{m}$ length, totaling $10 \mathrm{~m}^{2}$. For the assessments, the two central row were evaluated, disregarding $0.5 \mathrm{~m}$ of each end. The useful area for assessment was $4 \mathrm{~m}^{2}$. Plots were set 1-m apart up from each other. To maintain crop phytosanitary conditions, clorantraniliprole+lambdacyhalothrin (Besiege ${ }^{\circledR}, 15+7.5 \mathrm{~g}$ ai ha $^{-1}$, Syngenta, Brazil) and epoxiconazol+pyraclostrobin (Opera ${ }^{\circledR}, 50+133 \mathrm{~g}$ ai ha ${ }^{-1}$, Basf, Brazil) were applicated.

\section{Experimental design}

Both experiments were carried out in a randomized block design with eight replicates. Experiment I was set up in a two by two factorial design, testing two doses of glyphosate (Roundup Original ${ }^{\circledR}$, $360 \mathrm{~g}$ ea $\mathrm{L}^{-1}$; Monsanto, São José dos Campos, Brazil) (960 and 1,440 $\mathrm{g}$ ae ha ${ }^{-1}$ ) and two modes of application (single spraying and sequential spraying). Experiment II was set up in a two by three factorial design, testing two doses of glyphosate (960 and 1,440 $\mathrm{g}$ ae ha ${ }^{-1}$ ) and three doses of phosphate fertilization $(54,108$ and 162 $\mathrm{kg} \mathrm{ha}^{-1}$ of $\mathrm{P}_{2} \mathrm{O}_{5}$ ).

\section{Herbicide spraying conditions}

A glyphosate isopropylamine salt formulation was applied in a single spraying (960 or $1,440 \mathrm{~g}$ ae ha ${ }^{-1}$ ) at 28 days after crop emergence (DAE) (Experiment $I$ and II) or in a sequential spraying $\left(480+480\right.$ or $\left.960+480 \mathrm{~g}_{\text {ae }} \mathrm{ha}^{-1}\right)$ at 24 and 39 DAE (Experiment I). Glyphosate was sprayed by using a $\mathrm{CO}_{2}$ pressurized backpack sprayer equipped with flat-fan nozzles (8002; Jacto $^{\circledR}$, São Paulo, Brazil) delivering 2 gallons per minute in angle of spraying of $80^{\circ}$, calibrated to a spray a volume of $200 \mathrm{~L} \mathrm{ha}^{-1}$ and a pressure of $200 \mathrm{kPa}$. During herbicide application, we verified no cloudy conditions, wind speed of $\sim 3 \mathrm{~km} \mathrm{~h}^{-1}$ and temperature of $\sim 18{ }^{\circ} \mathrm{C}$.

\section{Phosphate fertilization}

We added a triple superphosphate fertilizer $\left(45 \%\right.$ of $\left.\mathrm{P}_{2} \mathrm{O}_{5}\right)$ manually into the soil (over the planting line) at three doses $\left(54,108\right.$ or $162 \mathrm{~kg} \mathrm{ha}^{-1}$ of $\left.\mathrm{P}_{2} \mathrm{O}_{5}\right)$, just after the time of sowing. This fertilization was done in addition to the soil acidity correction.

\section{Evaluation procedures}

In both experiments, we evaluated the weed community based on number of individuals and their respective dry mass accumulation, as well as the crop dry mass of leaves, dry mass of stem, dry mass of pods, dry mass of shoot, plant height and grain yield.

We collected two samples $(0.5 \mathrm{~m}$ by $0.5 \mathrm{~m})$ of all weeds present within the plot useful area just before crop harvesting. After counting the number of individuals, we put the weeds into a forced-air oven at $60{ }^{\circ} \mathrm{C}$ during seven days. After that, the dried plant material is weighted in a semianalytical balance $(0.01 \mathrm{~g})$ to determine the dry mass accumulation.

After weed collection, we harvested all soybean plants within the plot useful area to estimate the crop yield ( 15\% of humidity). In sequence, we gathered 20 soybean plants to measure the plant height and to determine the dry mass of leaves, dry mass of stem, dry mass of pods and dry mass of shoot, as described for the weed community.

\section{Statistical analysis}

Data were previously analyzed by Levene's test to verify the homogeneity of variances $(P=0.05)$. As this test was not significant $(P>0.05)$ for all variables (showing homogeneity of variances), we proceeded with the $F$ test $(P=0.05)$ and, complementary just for doses of phosphate fertilization, the regression analysis.

\section{Conclusion}

At the doses used, phosphate fertilization don't enhance glyphosate uptake, providing a safety application to glyphosate resistant soybean. The use of glyphosate in a sequential spraying $\left(960+480 \mathrm{~g} \mathrm{ha}^{-1}\right.$ of acid equivalent) or in higher doses $\left(1,440 \mathrm{~g} \mathrm{ha}^{-1}\right.$ of acid equivalent) resulted in 
highly efficient weed control and higher soybean production. Phosphate fertilization changed weed community development, increasing plants development but also guaranteed better soybean yield.

\section{Acknowledgements}

The authors would like to thank CNPq (National Counsel of Technological and Scientific Development) and FAPESP (São Paulo State Research Foundation) for the researcher's scholarships. We thank Pricilla Aparecida Barbosa for helping with trials conduction.

\section{References}

Albrecht LP, Albrecht AJP, Braccini AL, Oliveira JR, Zobiole LHS, Ávila MR (2014a) The role of glyphosate in RR soybean production and seed quality. Planta Daninha. 32:401-407.

Albrecht AJP, Albrecht LP, Krenchinski FH, Placido HF, Lorenzetti JB, Victoria-Filho R, Barroso AAM (2014b) Behavior of RR soybeans subject to different formulations and rates of glyphosate in the reproductive period. Planta Daninha. 32:851-859.

Alonso DG, Constantin J, Oliveira RS, Santos G (2013) Selectivity of glyphosate alone or in tank mixtures for RR soybean in sequential applications. Planta Daninha. 31:203212.

Bayle V, Arrighi JF, Creff A, Nespoulous C, Vialaret J, Rossignol M, Gonzalez E, Paz-Ares J, Nussaume L (2011) Arabidopsis thaliana high-affinity phosphate transporters exhibit multiple levels of posttranslational regulation. The Plant Cell. 23:1532-1535.

Brahim S, Niess A, Pelipsen M, Neuhoff D, Scherer H (2017) Effect of combined fertilization with rock phosphate and elemental Sulphur on yield and nutrient uptake of soybean. Plant Soil Environ. 63:89-95.

CÉLERES. Biotechnology report. 2017. http://www.celeres.com.br/1o-levantamento-de-adocao-dabiotecnologia-agricola-no-brasil-safra-201617/<Accessed on 20 Nov. 2017>

Culpepper AS, York AL, Batts RB, Jennings KM (2000). Weed management in glufosinate and glyphosate-resistant soybean (Glycine max). Weed Tech. 14:77-88.

Duke SO, Lydon J, Koskinen WC, Moorman TB, Chaney RL, Hammer Schmidt R (2012) Glyphosate effects on plant mineral nutrition, crop rhizosphere microbiota, and plant disease in glyphosate-resistant crops. J Agr Food Chem. 60:10375-10397.

Duke SO, Powles SB (2008) Glyphosate: a once-in-a-century herbicide. Pest Manag Sci. 64:319-325.

Ferrel JA, Witt WW (2002) Comparison of glyphosate with other herbicides for weed control in corn (Zea mays): Efficacy and economics. Weed Tech. 16:701-706.
Fuchs MA, Geiger DR, Reynolds TL, Bourque JE (2002) Mechanisms of glyphosate toxicity in velvetleaf (Abutilon theophrastii medikus). Pestic Biochem Phys. 74:27-39.

Funke T, Han H, Healy-Fried ML, Fischer M, Schonbrunn E (2006) Molecular basis for the herbicide resistance of roundup ready crops. P Natl Acad Sci USA. 103:13010-13015.

Gianessi LP (2008) Economic impacts of glyphosate-resistant crops. Pest Manag Sci. 64:346-352.

Gomes MP, Bicalho EM, Smedbol E, Cruz FV, Lucotte M, Garcia QS (2017) Glyphosate can decrease germination of glyphosate-resistant soybeans. J Agric Food Chem. 65:22792286.

Hetherington PR, Marshall G, Kirkwood RC, Warner JM (1998) Absorption and efflux of glyphosate by cell suspensions. J Exp Bot. 49:527-533.

Hirsch J, Marin E, Floriani M, Chiarenza S, Richaud P, Nussaume L, Thibaud MC (2006) Phosphate deficiency promotes modification of iron distribution in Arabidopsis plants. Biochimie. 88:1767-1771.

Krenchinski FH, Albrecht LP, Albecht AJP, Cesco VJS, Rodrigues DM, Portz RL, Zobiole LHS (2017) Glyphosate affects chlorophyll, photosynthesis and water use of four Intacta RR2 soybean cultivars. Acta Physiol Plant. 39:1-12.

Reddy KN, Rimando AM, Duke SO (2004) Aminomethylphosphonic acid, a metabolite of glyphosate, causes injury in glyphosate-treated, glyphosate-resistant soybean. J Agric Food Chem. 52:5139-5143.

SBCS - Sociedade Brasileira de Ciência do Solo. 2004. Manual de adubação e calagem para os Estados do Rio Grande do Sul e Santa Catarina. Comissão de Química e Fertilidade do Solo, Porto Alegre, Brazil. $400 \mathrm{p}$.

Zanatta TSC, Manica-Berto R, Ferreira CD, Cardozo MM, Rombaldi CV, Zambiazi RC, Dias AR (2017). Phosphate fertilizer and growing environment change the phytochemicals, oil quality, and nutritional composition of Roundup Ready genetically modified and conventional soybean. J Agric Food Chem. 65:2661-2669.

Zobiole LHS, Oliveira JR, Constantin J, Oliveira JR. A, Castro C, Oliveira FA, Kremer RJ, Moreira A, Romagnoli LM (2012) Nutrient accumulation in conventional and glyphosateresistant soybean under different types of weed control. Planta Daninha. 30:75-85.

Zobiole LHS, Oilveira JR. RS, Kremer RJ, Muniz AS, Junior AO (2010a) Nutrient accumulation and photosynthesis in glyphosate-resistant soybeans is reduced under glyphosate use. J Plant Nutr. 33:1860-1873.

Zobiole LHS, Oliveira JR, Kremer RJ, Constantin J, Bonato CM, Muniz AS (2010b) Water use efficiency and photosynthesis of glyphosate-resistant soybean as affected by glyphosate. Pestic Biochem Physiol. 97:182-193.

Zobiole LHS, Kremer RJ, Oliveira JR. RS, Constantin J (2011) Glyphosate affects microorganisms in rhizospheres of glyphosate-resistant soybeans. J Appl Microbiol. 110:118127. 